\title{
TICC Guides
}

\section{TICC GUIDES AVAILABLE FROM NALLD PUBLICATIONS CENTER}

\begin{abstract}
One of the purposes for which NALLD was founded was to facilitate lab directors helping each other, and sharing their ideas. Making Tape Set TICC GUIDES available through our NALID Publications Center was a natural extension of this idea.
\end{abstract}

For the uninftiated, TICC stands for Tape Index Correlation Code. It is a detailed guide which tells how each reel of tape correlates to the printed text by chapter, page, and type of exercise. Some also give times for each drill. These TICC GUIDES are the heart of a sound information retrieval system for the tape library. They allow both teacher and student to use tapes more effectively in planning a course of study.

Every set of tapes should have such a guide. Since publishers do not always provide them, individual schools make up their own. Through NALLD, we can exchange such guides. Once you obtain another school's Guide, it is a simple mater to process your tapes to conform with the guide. Here is how the system works:

1. You must be a NALLD member to use this service.

2. Single copies of most TICC GUIDES are available from NALLD FREE, IF you follow these directions exactly.

3. We are unable to provide multiple copies. However, you have our permission to reproduce or copy any material received from the Publications Center provided you identify the source by the line:

--Reprinted by permission of the National Association of Language Laboratory Directors.

4. The TICC GUIDE portion of the Publications Center has been moved to The University of Wisconsin-Madison.

a. Send a $10 \times 13$ inch manila envelope, which is pre-addressed.

b. The envelope must be stamped with sufficient postage for all items requested plus an additional $1 / 2 \mathrm{oz}$. for the envelope. The weight of each item is listed below.

c. Your request must be on one of our NALLD order blanks (original or photo copy) which are distributed with each issue of the Journal.

5. The TICC GUIDES listed below in this issue are just the ones most recently completed, Other lists of TICC GUIDES have been published in earlier issues of the JOURNAL (such as May, 1970; October 1971; December 1971).

We have TICC GUIDES in the following twenty-seven (27) languages, which are available to NALLD members:

$\begin{array}{lllll}\text { AMHARIC } & \text { DUTCH } & \text { HEBREW } & \text { NORWEGIAN } & \text { SWAHILI } \\ \text { ARABIC } & \text { ENGLISH AS A FL } & \text { ICELANDIC } & \text { PERSIAN } & \text { SWEDISH } \\ \text { BENGALI } & \text { FRENCH } & \text { ITALIAN } & \text { PORTUGUESE } & \text { TAGALOG } \\ \text { BULGARLAN } & \text { GERMAN } & \text { JAPANESE } & \text { RUSSIAN } & \text { THAI } \\ \text { CHINESE } & \text { GREEK } & \text { LINGUISTICS } & \text { SPANISH } & \text { TURRISH } \\ \text { CHINYANJA } & & & & \text { YORUBA }\end{array}$




\section{TICC Guides}

You may obtain our most uptodate, complete "LIST(S) of available TICC GUIDES" in any language(s) by one of the following methods:

A. Requests for LISTS of Available TICC GUIDES, IN A SINGLE LANGUAGE can be obtained by:

(1) Sending us a self-addressed, stamped return envelope.

(2) Indicating in a note which language list you are interested in.

B. Requests for ALL 1ists, in ALL LANGUAGES can be obtained by:

(1) Sending us a $10^{\prime \prime} \times 13^{\prime \prime}$ self-addressed manila envelope, stamped with 32 cents postage.

(2) Sending us one dollar's $(\$ 1.00)$ worth of US Postage Stamps to pay for the Xerox costs.

(3) Sending us a note telling us that you want "List of All Available TICC GUIDES in All Languages."

6. Following are the TICC GUIDES which have become available since the last list was published in the December, 1971 NALLD JOURNAL (Vol. VI, No. 2):

\begin{tabular}{|c|c|c|c|c|}
\hline $\begin{array}{l}\text { UW TICC } \\
\text { NUMBER }\end{array}$ & $\begin{array}{l}\text { NO.OF } \\
\text { REELS }\end{array}$ & AUTHOR-TITLE-PUBLI SHER-DATE & EDITION & $\begin{array}{l}\text { WEIGHT } \\
\text { IN OZ. }\end{array}$ \\
\hline $\mathrm{CH} 1.012$ & 10 & $\begin{array}{l}\text { Huang and Kok, SPEAK CANTONESE, BOOK I } \\
\text { (Far Eastern Publications, Yale } \\
\text { University, 1963) }\end{array}$ & $1 s t$ & 1.25 \\
\hline CJ 1.001 & 30 & Stevick, CHINYANJA BASIC COURSE (FSI 1965) & $1 s t$ & 0.75 \\
\hline FR2.011 & 36 & $\begin{array}{l}\text { Metz, REFLETS DU MONDE FRANCAIS (McGraw } \\
\text { Hi11 1971) }\end{array}$ & 1st & 1.25 \\
\hline FR2.012 & 22 & $\begin{array}{l}\text { Bauer, LIRE, PARLER ET ECRIRE (Holt, } \\
\text { Rinehart, Winston 1971) }\end{array}$ & Rev. & 0.75 \\
\hline FR3.013 & 26 & $\begin{array}{l}\text { Valdman et al., DRILLBOOK OF FRENCH } \\
\text { PRONUNCIATION (Harper and ROW, 1970) }\end{array}$ & 2nd & 2.25 \\
\hline FR3.017 & 2 & $\begin{array}{l}\text { Hof fman, LA PRATIQUE DU FRANCAIS PARLE } \\
\text { (Scribner's 1973) }\end{array}$ & 1st & 0.50 \\
\hline FR3.018 & 4 & $\begin{array}{l}\text { Sussex Tapes, TALKING IN FRENCH (Holt, } \\
\text { Rinehart, Winston nd) }\end{array}$ & lst & 0.50 \\
\hline GR2.021 & 16 & $\begin{array}{l}\text { Hammond, FORTBILDUNG IN DER DEUTSCHEN SPRACHE } \\
\text { (Oxford.U. 1969) }\end{array}$ & 1st & 0.50 \\
\hline $\mathrm{HE} 1.011$ & 2 & Mansoor, FIRST SEMESTER HEBREW, Revised & $4 \mathrm{th}$ & 1.00 \\
\hline RU1.013 & 16 & $\begin{array}{l}\text { Rudy et al., RUSSIAN: A COMPLETE ELEMENTARY } \\
\text { COURSE }\end{array}$ & $1 \mathrm{st}$ & 2.00 \\
\hline RU1.015 & 27 & $\begin{array}{l}\text { Stilman \& Harkins, INTRODUCTORY RUSSIAN } \\
\text { GRAMMAR (Xerox College Publishing 1972) }\end{array}$ & 2nd & 0.50 \\
\hline SHl. 005 & 40 & $\begin{array}{l}\text { Zawawa, KISWAHILI KWA KITENDO (Harper \& Row } \\
\text { 1971) }\end{array}$ & $1 s t$ & 0.75 \\
\hline TK1.001 & 52 & Swift, TURKISH BASIC COURSE (FSI 1966) & 1st & 1.25 \\
\hline
\end{tabular}




\section{TICC Guides}

NALLD Order Blank for TICC GUIDES

Send this order blank, or a photo copy of it, along with a $10^{\prime \prime} \times 13^{\prime \prime}$ manila envelope which is self-addressed and STAMPED with the proper return postage (according to the weight of materials ordered PLUS 1/2 oz, for envelope) to:

Mr. T. R. Goldsworthy, Director LABORATORIES FOR RECORDED INSTRUCTION

The University of Wisconsin-Madison

Room 279 Van Hise Hal1, 1220 Linden Drive

Madison, Wisconsin 53706

\begin{tabular}{|l|l|l|l|}
\hline TICC NO. & LANGUAGE & AUTHOR -TITLE & $\begin{array}{l}\text { WE IGHT } \\
\text { IN OZ. }\end{array}$ \\
\hline & & & \\
\hline & & & \\
\hline & & & \\
\hline & & & \\
\hline \\
Requested by: (please type or print) \\
Name: \\
$\begin{array}{l}\text { School: } \\
\text { Address: }\end{array}$ \\
\hline
\end{tabular}

City \& State:

ZIP CODE :

I AM CURRENTLY A PAID-UP MEMBER OF NALLD

(signed)

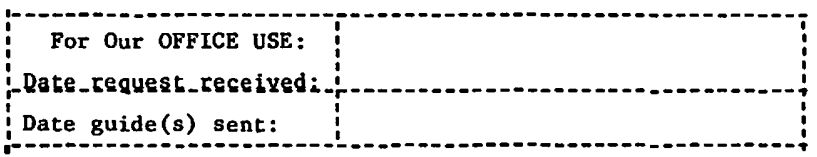

